\title{
Medieval Farming Practices in Deserted Villages Can be Determined Based on the Nitrogen Isotopic Signature in Recent Forest Soils
}

\author{
Kateřina Součkováa, Michal Hejcman ${ }^{\mathrm{a}, b^{*}}$, Tomáš Klír ${ }^{\mathrm{b}}$ \\ ${ }^{a}$ Department of Ecology, Faculty of Environmental Sciences, Czech University of Life Sciences Prague, Kamýcká 129, CZ-165 21 Prague, Czech Republic \\ ${ }^{b}$ Institute of Prehistory and Early History, Faculty of Arts, Charles University in Prague, Náměstí Jana Palacha 2, CZ-116 38 Prague 1, Czech Republic
}

\section{ARTICLE INFO}

\section{Article history:}

Received: 25. March 2013

Accepted: 9. July 2013

\section{Key words:}

isotope

former land use

manure

middle-ages

organic fertilizer application

\begin{abstract}
$A B S T R A C T$
Using $\delta^{15} \mathrm{~N}$ analysis of soil organic matter in two deserted medieval villages and their agricultural land in different environmental conditions in the Czech Republic, the aim of this study was to study the application of organic fertilizers on medieval agricultural land.

The study was performed in the villages of Roudnička (430-455 m a.s.1.) and Spindelbach (800-880 m a.s.1.), both established in the $13^{\text {th }}$ century and deserted in the $15^{\text {th }}$ century and covered by Norway spruce (Picea abies) forest at present. Soil samples of humus horizon (Ah) were collected in close vicinity to the former buildings and in the deserted medieval fields in autumn 2011.

No significant differences were recorded in $\delta^{15} \mathrm{~N}$ among the soil samples collected in close vicinity to the ruins of the buildings or in the former field in Roudnička. Despite there being no significant effect in terms of the position, there were clear trends with the lowest values of $\delta^{15} \mathrm{~N}$ recorded in close vicinity to the buildings, and the highest values recorded in the former field. The $\delta^{15} \mathrm{~N}$ signature was significantly higher in close vicinity to the ruins of the buildings than in the former fields in Spindelbach in all probability indicating deposition of organic fertilizers connected with livestock breeding close to the houses. In both deserted villages, $\delta^{15} \mathrm{~N}$ signature significantly decreased on the former agricultural land with the distance from the village indicating a decrease in deposition of organic fertilizers with the distance from the farm buildings.

We concluded that $\delta^{15} \mathrm{~N}$ signature generated by medieval farming practices can be detected in contemporary forest soils and $\delta^{15} \mathrm{~N}$ signature can be thus used for the study of ancient farming practices.
\end{abstract}

\section{Introduction}

The main aim of landscape archaeology is to study questions connected with agricultural land use in the past. The question as to whether and how much organic fertilizers were used on medieval agricultural land in Central Europe has never been adequately answered. To identify the application of organic fertilizers, an analysis of stable nitrogen $(\mathrm{N})$ isotopes in the soil organic matter can be used (Bakels 1997; Bol et al. 2005; Senbayram et al. 2008). In Central Europe, organic fertilizers which could have been used during the Middle Ages include feces of animals, urine, farm yard manure, dung water and slurry. Nitrogen has two stable isotopes, lighter ${ }^{14} \mathrm{~N}$ and heavier ${ }^{15} \mathrm{~N}$, with an extremely constant ratio $99.63 \%$ of ${ }^{14} \mathrm{~N}$ and $0.37 \%$ of ${ }^{15} \mathrm{~N}$ in the air (Junk, Svec 1958). In organic materials, the proportion of $\mathrm{N}$ isotopes is frequently

*Corresponding author. E-mail: hejcman@fzp.czu.cz different than in the air (expressed as $\delta^{15} \mathrm{~N}$ ) as it is affected by numerous biochemical processes (Robinson 2001). The application of organic fertilizers enriches the soil by ${ }^{15} \mathrm{~N}$ and the application of organic fertilizers can consequently be identified according to the increased $\delta^{15} \mathrm{~N}$ in the soil organic matter and in the plants growing in such soils (Bol et al. 2005; Georgi et al. 2005; Ellert, Janzen 2006; Kriszan et al. 2009). This is due to the enrichment of $\delta^{15} \mathrm{~N}$ up the food chain, with the plants having distinctly lower values than the herbivores which consume them. In addition, lighter ${ }^{14} \mathrm{~N}$ leaks more easily during an ammonia volatilization from feces than ${ }^{15} \mathrm{~N}$ (Bol et al. 2005; Bogaard et al. 2007; Senbayram et al. 2008). An increased $\delta^{15} \mathrm{~N}$ can be detected in soil organic matter or in the biomass of recent plant species a number of years after the last organic fertilizer application (Koerner et al. 1999; Commisso, Nelson 2007; Sah, Ilvesniemi 2007; Fraser et al. 2011). In Northern France almost a century after afforestation of the territory of a deserted village, for example, Koerner et al. (1999) recorded 


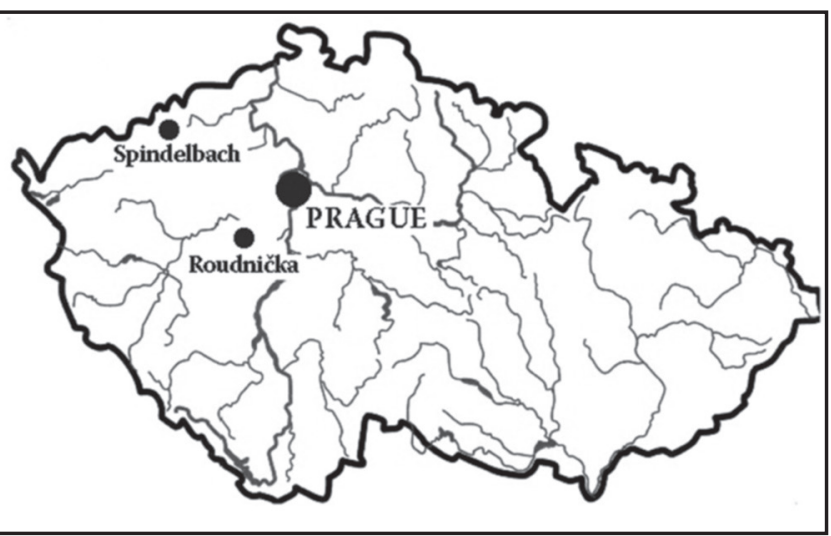

Figure 1. Map of the Czech Republic with an indication of Prague (the Capital) and the two studied deserted medieval villages Roudnička and Spindelbach.

the lowest $\delta^{15} \mathrm{~N}$ in soil organic matter and also in the biomass of Dryopteris carthusiana in ancient forests. It was higher in former pastures, followed by former croplands, meadows and the highest in formerly intensively fertilized gardens. Dupouey et al. (2002) recorded increased $\delta^{15} \mathrm{~N}$ in soil organic matter and in the leaves of recent oaks (Quercus sp.) in North-eastern France, which reflected manure application during Roman times. Based on compound specific $\delta^{15} \mathrm{~N}$ amino acid signals in anthropogenic palaeosols from Orkney, Simpson et al. (1999a; 1999b) demonstrated that the relicts of medieval to early modern soils retained a signature which suggests cereal cultivation, with a later phase of manured grassland. Fossil Bronze Age soils retained signals which suggest continuous cereal cultivation only.

Although stable $\mathrm{N}$ isotopes have been used in archaeological research frequently over the last 30 years (Vogel, van der Merwe 1977; DeNiro 1987), this method has never been applied to the study pattern of organic fertilizers application in deserted medieval villages in Central Europe. A number of deserted villages together with the pattern of their fields have been identified in the last century in the Czech Republic (Černý 1994; Nekuda 2005; Nekuda 2007; Klír 2009, 2010; Vařeka et al. 2011; Hejcman et al. 2010; 2011; 2013; Klápště 2012), although their agricultural history is still not that well known. The advantage of the numerous deserted villages is that they were afforested after their abandonment and consequently the medieval agricultural land has not been affected by modern agricultural activities making them excellent sites for the use of $\delta^{15} \mathrm{~N}$ analysis for investigation of medieval farming practices.

The production of organic fertilizers is also inherently connected with the breeding of livestock. It is assumed that locales with high concentration of livestock, for example, enclosures or barns, retain higher $\delta^{15} \mathrm{~N}$ in the soil than pastures, meadows or arable fields. In addition, as the application of organic fertilizers (in particular farm yard manure during the Middle Ages) on agricultural land is a work of labour, we hypothesize that the application of organic fertilizers decreased with the distance from the village as this has been recorded in numerous recent analogies in rural regions of Central Europe. This assumption is based on rationalisation of the farming work. Fertilizing fields close to the village decreases investment into energy and the time for the fertilizer transport and application. In addition, organic fertilizers increases crop yields close to the village and consequently the farmer invests less energy and time when transporting the harvested crops home. If the assumption of a decrease in the application of organic fertilizers with the distance from the village is correct, there must be a decrease in $\delta^{15} \mathrm{~N}$ signature with the distance from the deserted village on former agricultural land.

Using $\delta^{15} \mathrm{~N}$ analysis of soil organic matter in two deserted medieval villages and their agricultural land in different environmental conditions in the Czech Republic, the aim of this study was to determine the application of organic fertilizers on medieval agricultural land. In addition, a stone enclosure was identified in one of the two investigated villages. Using $\delta^{15} \mathrm{~N}$ analysis, we aimed at identifying whether this enclosure was used for livestock breeding or for different purposes. Comparing the values of $\delta^{15} \mathrm{~N}$ in close vicinity to the ruins of buildings and former agricultural land, we focused on estimating the differences in livestock breeding systems between the investigated deserted villages.

\section{Material and methods}

\subsection{Study sites}

The study was performed at two archaeological sites in the Czech Republic (Figure 1). The first, the deserted medieval village of Roudnička, is situated in the south-west part of the Czech Republic in close proximity to the current

Table 1. Basic characteristics of the investigated deserted medieval villages of Roudnička and Spindelbach.

\begin{tabular}{lll}
\hline & \multicolumn{1}{c}{ Roudnička } & \multicolumn{1}{c}{ Spindelbach } \\
\hline Altitude (m a.s.l.) & $430-455$ & $800-880$ \\
Length of extinct field $(\mathrm{m})$ & $\sim 400$ & $\sim 800$ \\
Slope of land & $1-3^{\circ}$ & $3-7^{\circ}$ \\
Soil type & Dystric Cambisols & Dystric Cambisols \\
$\mathrm{pH}\left(\mathrm{H}_{2} 0\right)$ & 4.35 & 4.13 \\
$\mathrm{pH}\left(\mathrm{CaCl}_{2}\right)$ & 3.82 & 3.65 \\
Mean annual temperature $\left({ }^{\circ} \mathrm{C}\right)$ & 7.5 & 5 \\
Mean annual precipitation $(\mathrm{mm})$ & 600 & 1,000 \\
\hline
\end{tabular}




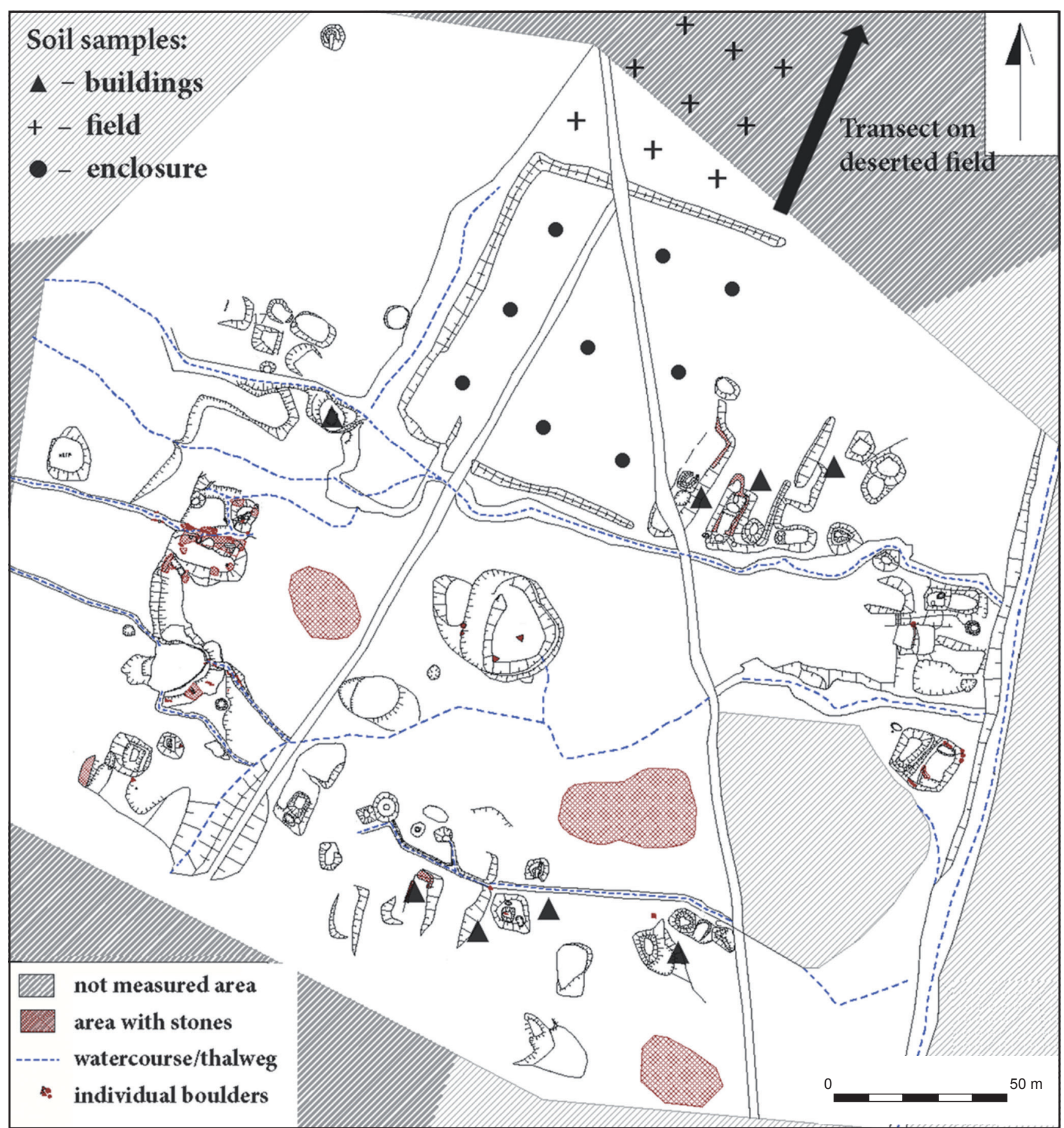

Figure 2. Plan of the deserted medieval village of Roudnička. The marks indicate the positions of the soil sampling sites.

village of Běštín, $40 \mathrm{~km}$ south-west of Prague $\left(49^{\circ} 48^{\prime} 49^{\prime \prime} \mathrm{N}\right.$, $\left.13^{\circ} 59^{\prime} 57^{\prime \prime} \mathrm{E}\right)$. The grounds of the deserted village is at an altitude of $430-455 \mathrm{~m}$ a.s.l. on the southeast edge of the Plešivec Massif (654 $\mathrm{m}$ a.s.l.). On an area of six and eight hectares, seventy anthropogenic surface objects were discovered and interpreted as relicts of medieval courtyards (Korbová Procházková 2011). The deserted Roudnička was a regularly arranged village. The relicts surround a four-sided open space with dimensions of $140 \times 70$ metres (village square). The individual relicts were grouped into
12-15 courtyards. We are of the opinion that the courtyards comprised residential and agricultural buildings. Dated according to pottery, the village of Roudnička was in all probability established in the $13^{\text {th }}$ century and abandoned in the $15^{\text {th }}$ century. The first written record concerning the village dates back to the year 1547 with the village being mentioned as deserted even at this time.

At present, the deserted village is in a Norway spruce (Picea abies) forest with the age of the trees ranging from 40 to 90 years of age. Detailed information concerning the 


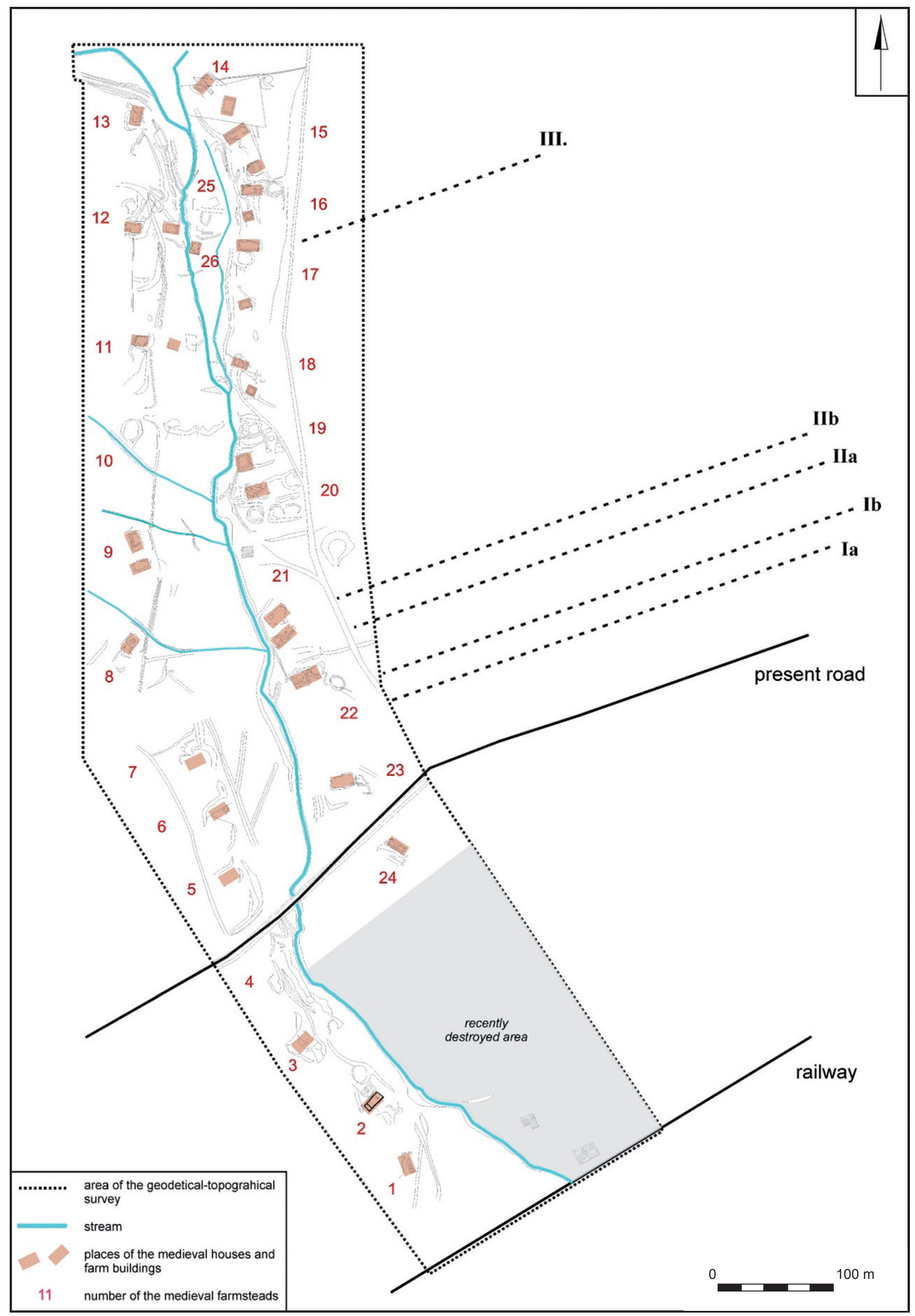

Figure 3. Plan of the deserted medieval village of Spindelbach. The lines (Ia, Ib, IIa, IIb and III) indicate the individual transects where the soil samples were collected in the direction from the village to the end of the deserted agricultural land (former fields). 
natural conditions of the village are provided in Table 1 and the plan of the village is shown in Figure 2. One clear remnant of the medieval field $350 \mathrm{~m}$ long was identified according to its delimitation by well visible stone borders.

The second, the deserted medieval village called Spindelbach, is situated in the north-west part of the Czech Republic in close proximity to the current village of Výsluní, $120 \mathrm{~km}$ north-west of Prague $\left(50^{\circ} 29^{\prime} \mathrm{N}, 13^{\circ} 11^{\prime} \mathrm{E}\right)$, at an altitude of $800-880 \mathrm{~m}$ a.s.l. in the central part of the Ore Mountains (Krušné hory and Erzgebirge in Czech and German, Figure 1). Dated based on pottery, the village was in all probability established in the $2^{\text {nd }}$ half of the $13^{\text {th }}$ century (Crkal, Črná 2009). The first written record dates back to the year 1356 and the village was in all probability abandoned in the $2^{\text {nd }}$ half of the $15^{\text {th }}$ century. The deserted Spindelbach consisted of great linear settlements with parcels of strips having farmstead access (so-called "Waldhufendorf" in German). Circa 30 abandoned medieval farmsteads were identified and documented. The lands belonged to particular farmsteads and are well identifiable from hedgerows agrarian terraces.

At present, the deserted village is in a Norway spruce (Picea abies) forest with the age of the trees ranging from 40 to 90 years of age. Detailed information concerning the natural conditions are provided in Table 1 and the plan of the village is shown in Figure 3.

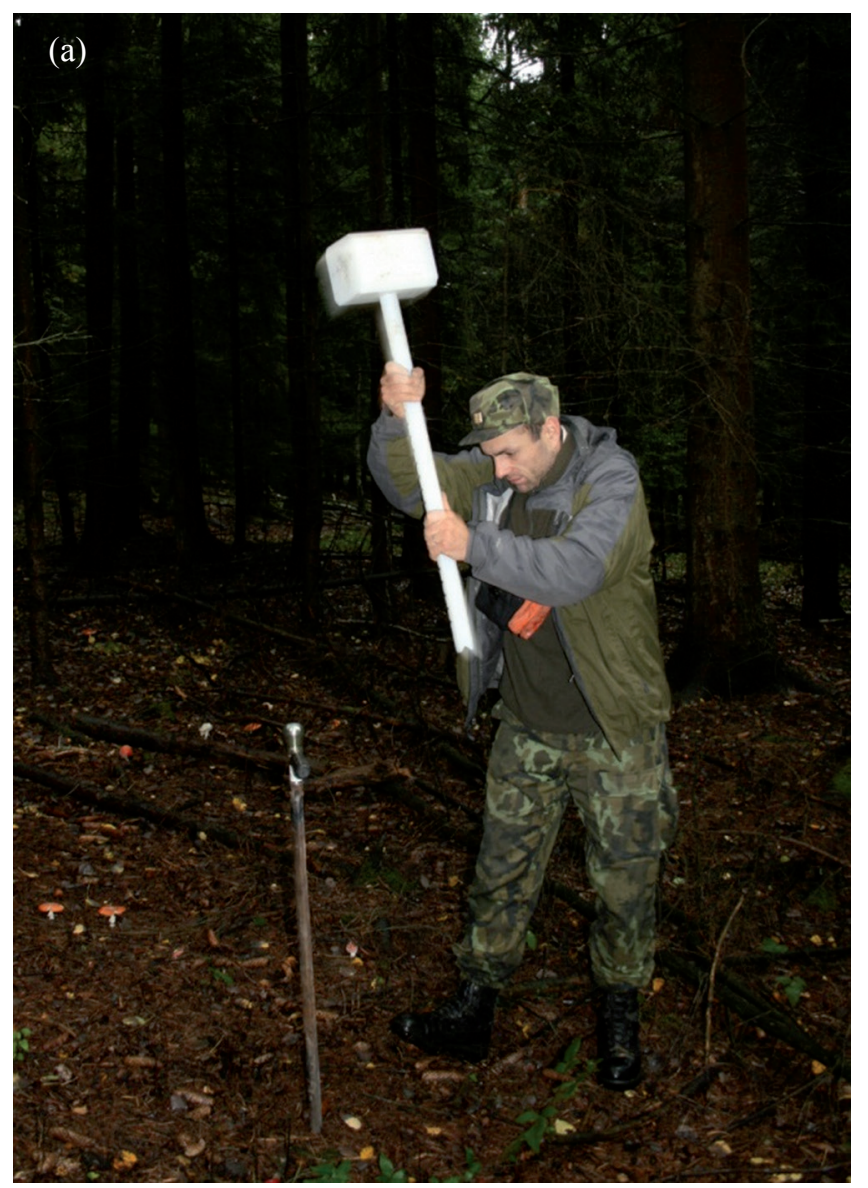

\subsection{Soil samples collection and analysis}

Soil samples were collected in September 2011 using a soil probe $5 \mathrm{~cm}$ in diameter. The cover of the understory plants was less than $1 \%$ at both sites. The $\delta^{15} \mathrm{~N}$ was identified in the humus (Ah) horizon from a depth of $2-5 \mathrm{~cm}$ from the soil surface (Figure 4). Each soil sample was a mixture of four sub-samples collected within the circle with $1 \mathrm{~m}$ diameter around each sampling point. The collected soil samples were air-dried and sieved through $1 \mathrm{~mm}$ sieve before the $\mathrm{N}$ isotopes analysis. The soil samples were collected (1) in close vicinity to the former buildings in the village of Roudnička $(n=8) ;(2)$ in the stone enclosure $(n=9)$, and (3) in the abandoned medieval field ( $n=15$; Figure 2 ). We only took samples in one field as the relicts from the other fields were not reliably identified. Three parallel transects of soil samples were collected in the enclosure and in the former field on the gradient at a distance from the ruins of the medieval buildings. In the former field, the distances from the beginning of the field and between the individual sampling sites are provided in Figure 5a. We took soil samples at six distances from the beginning of the former field, but in three last distances from the beginning of the field $(240,345$, and $365 \mathrm{~m}$ ), only two soil samples were taken as part of the relict of the former field was damaged by recent forest roads.

Soil samples were collected at five transects from the ruins of the buildings up to the end of the identified relicts

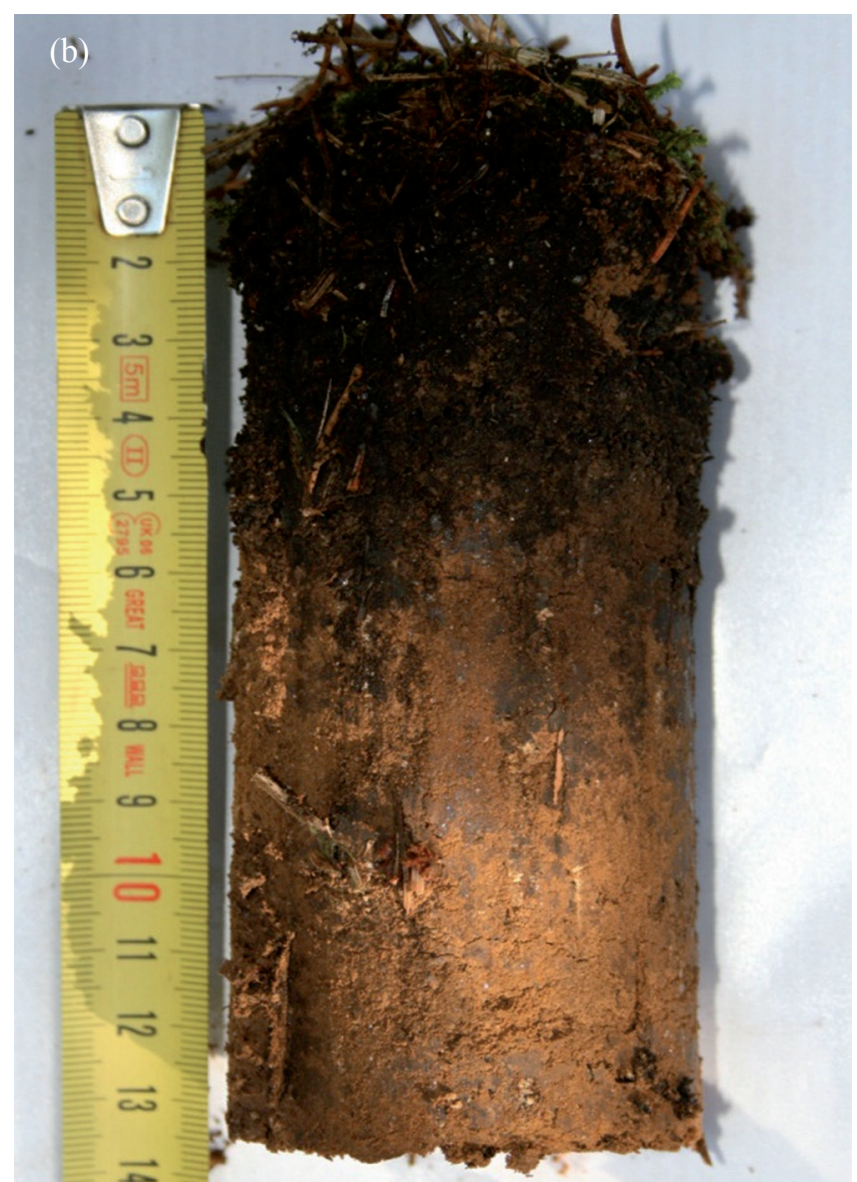

Figure 4. (a) The collection of soil samples by the soil probe (diameter $5 \mathrm{~cm}$ ) at the deserted medieval village of Roudnička and an example of the soil sample collected from the deserted village of Spindelbach. The content of $\delta^{15} \mathrm{~N}$ was only measured in the Ah horizon. 
of the three medieval fields in the village of Spindelbach (Figure 3). The distances from the ruins of the buildings and between the individual sampling sites are provided in Figures $5 \mathrm{~b}$ and $5 \mathrm{c}$. The four transects (marked as Ia, Ib, IIa and $\mathrm{IIb}, n=28$ ) were approximately $800 \mathrm{~m}$ long and we collected soil samples at six distances from the ruins of the buildings. One transect (III, $n=6$ ) was only $150 \mathrm{~m}$ long and we also collected soil samples at six distances from the ruins of the buildings, although these distances were not the same as in transects Ia - IIb. We therefore analysed and visualised the transect III separately.

The isotopic analyses were performed using a EuroEA 3028-HT elemental analyzer (EuroVector, Milan, Italy) connected with an isotope ratio mass spectrometer (IRMS Isoprime) in an accredited laboratory in the Crop Research Institute in Prague-Ruzyně, Czech Republic.

\subsection{Data analysis}

One-way ANOVA in Statistics 8.0 software (Stat Soft, Tulsa, USA) was used to evaluate the $\delta^{15} \mathrm{~N}$ in the soil samples. In case of a significant ANOVA result, the Tukey HSD post hoc test was used to evaluate the differences among the vicinity of the buildings, the enclosure and the field. Linear least square regression was used to detect the effect of the distance from the village on the $\delta^{15} \mathrm{~N}$ in the soil samples.

\section{Results}

The nitrogen isotopic signatures recorded in the soil samples collected in both the deserted villages and their fields are provided in Table 2. No significant differences in $\delta^{15} \mathrm{~N}$ among the soil samples collected in close vicinity to the building ruins, in the enclosure and in the former field were recorded in Roudnička. Despite no significant effect on the part of the position, there were clear trends with the lowest values of $\delta^{15} \mathrm{~N}$ recorded in close vicinity to the buildings, higher values recorded in the enclosure and the highest values recorded in the former field. The $\delta^{15} \mathrm{~N}$ signature was completely opposite from Roudnička in Spindelbach (Table 2). Significantly higher $\delta^{15} \mathrm{~N}$ were recorded in close vicinity to the building ruins as compared with the former fields. In both deserted villages, $\delta^{15} \mathrm{~N}$ signature significantly decreased with the distance from the village on the former agricultural land. The decrease was clearly linear within the identified $350 \mathrm{~m}$ long fragment of the former field in Roudnička (Figure 5a). The linear decrease in $\delta^{15} \mathrm{~N}$ signature was also recorded in Spindelbach, although the linear trend was not as clear as in the case of Roudnička (Figures $5 \mathrm{~b}$ and $5 \mathrm{c}$ ). In the case of transects Ia, Ib, IIa and IIb, a steep decrease in $\delta^{15} \mathrm{~N}$ signature was recorded at a distance up to $100 \mathrm{~m}$ from the buildings. A further decrease in $\delta^{15} \mathrm{~N}$ signature was recorded in Ia and Ib transects, but not in IIa and IIb transects at a distance between $100 \mathrm{~m}$ and $250 \mathrm{~m}$. With the exception of IIb transect, the values recorded at a distance $250 \mathrm{~m}$ were consistent with the values recorded at a distance $750 \mathrm{~m}$ at the end of the relict of the former field. In contrast, however, the values of $\delta^{15} \mathrm{~N}$ in Ia and IIa transects were higher at a distance of $500 \mathrm{~m}$ than in $250 \mathrm{~m}$ and $750 \mathrm{~m}$.

In the case of short transect III, we identified a clear decreasing trend of $\delta^{15} \mathrm{~N}$ values from the close vicinity of the ruins of the buildings up to the end of the identified former field (Figure $5 \mathrm{c}$ ). The values $\delta^{15} \mathrm{~N}$ recorded at distances from 20 to $50 \mathrm{~m}$ were constant and were intermediate between the values recorded in close vicinity to the ruins of the buildings and at the end of the former field.

\section{Discussion}

The primary finding from this study is that $\delta^{15} \mathrm{~N}$ signature generated by medieval farming practices can be detected in contemporary forests. The next conclusion is that $\delta^{15} \mathrm{~N}$ signature in the soil organic matter affected by medieval farming practices can also be preserved at altitudes above $800 \mathrm{~m}$ a.s.l. with annual precipitation around $1000 \mathrm{~mm}$ and therefore with an intensive leaching regime in the soil profile. This is evident from a decrease in $\delta^{15} \mathrm{~N}$ values with the distance from the building ruins in both the investigated deserted medieval villages. The use of $\delta^{15} \mathrm{~N}$ signature therefore enables the mapping of medieval farming practices connected with the deposition of organic materials such as feces, urine, dung water, farm yard manure or slurry. The decrease in $\delta^{15} \mathrm{~N}$ values with the distance from the deserted villages on the medieval agricultural land indicates that organic fertilizers were in all probability commonly used to improve agricultural production in Central Europe. This is the first direct archaeological evidence for the use of organic fertilizers on medieval agricultural land in the Czech Republic. In the past, the application of organic fertilizers on medieval fields was only indirectly estimated from the presence of pottery shards on ancient agricultural land. This was because old pottery vessels were thrown out into

Table 2. Results for the analysis of recent forest soil samples from the two deserted villages in the Czech Republic

\begin{tabular}{lcc}
\hline Deserted village & Places of collection & Mean value of $\delta^{15} \mathrm{~N}(\%) \pm$ S.E. \\
\hline Roudnička & Vicinity of building $(n=8)$ & $-1.19 \pm 0.66$ \\
$\mathrm{~F}_{(2,33)}=1.94, P=0.159$ & Enclosure $(n=9)$ & $0.24 \pm 0.59$ \\
\hline Spindelbach & Field $(n=15)$ & $0.35 \pm 0.49$ \\
$\mathrm{~F}_{(1,31)}=19.21, P<0.001$ & Vicinity of building $(n=9)$ & $1.33 \pm 0.38$ \\
\hline
\end{tabular}

S.E. - the standard error of the mean. 

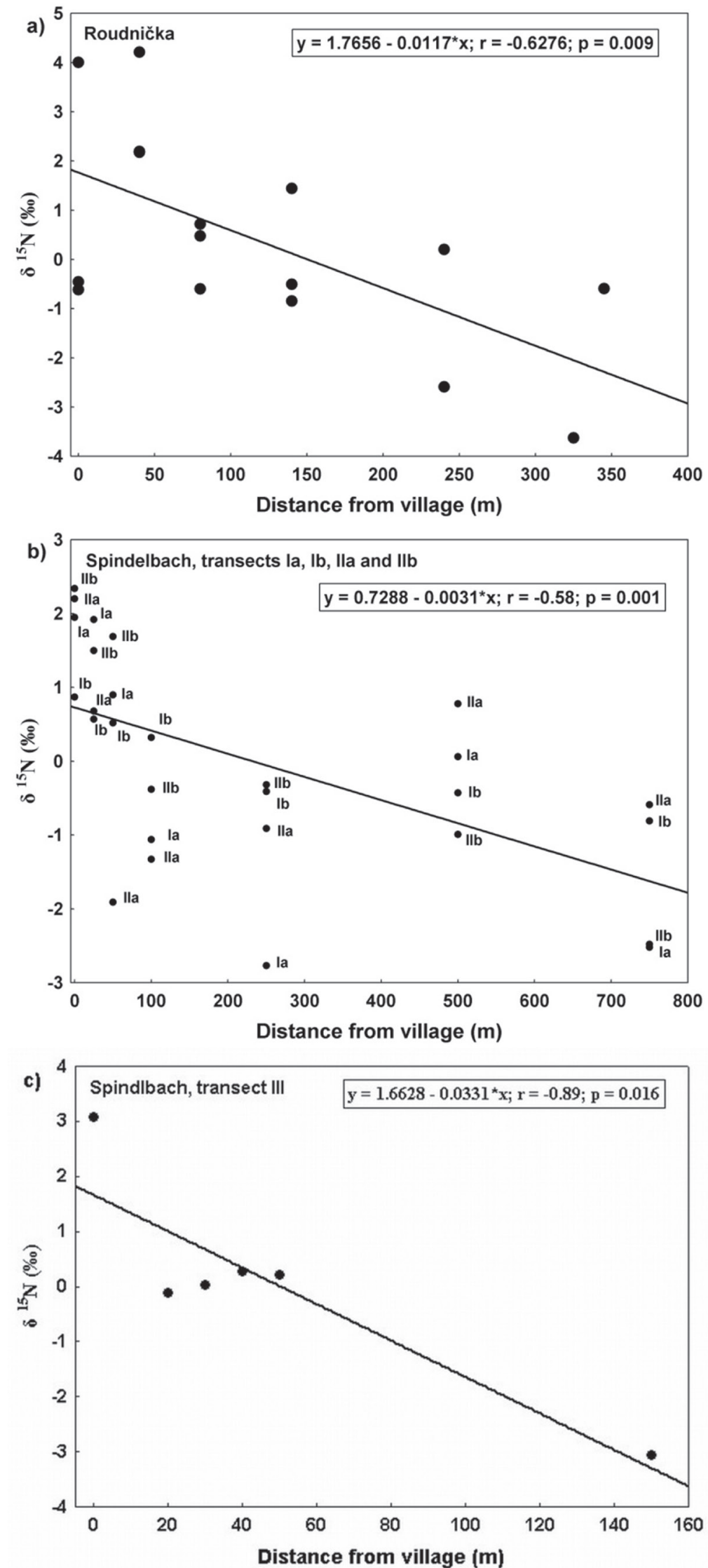

Figure 5. The correlation between the $\delta^{15} \mathrm{~N}$ in the soil samples and the distance from the village in the deserted agricultural lands in (a) Roudnička and (b), (c) Spindelbach. The names of the transects (Ia, Ib, IIa, IIb and III) in Spindelbach are in accordance with Figure 3. Transect III (c) was visualized separately because of its substantially shorter length than that of the other transects. 
manure and, along with manure, were applied to agricultural land, arable fields the most frequently (Bogaard et al. 2007; Klápště 2012). It is useful to make use of both approaches together and compare the results, although the problem is the low visibility of the pottery shards in forests and therefore the impossibility to collect them in a sufficiently high amount to construct reliable maps of their distribution. Pottery shards are well visible on arable land, but there can be an unwonted effect of recently applied organic fertilizers on $\delta^{15} \mathrm{~N}$ signature in soil organic matter disabling thus the use of $\delta^{15} \mathrm{~N}$ for detection of former application of organic fertilizers. The use of $\delta^{15} \mathrm{~N}$ signature for the detection of former farming practices must therefore be restricted to localities where no further organic fertilizers have been applied after the abandonment of the agricultural land.

The slightly higher $\delta^{15} \mathrm{~N}$ value in the relict of the former field than in the enclosure indicates that the enclosure was not used for livestock breeding in the village of Roudnička. In the case of the enclosure for livestock, the $\delta^{15} \mathrm{~N}$ value will be in all probability substantially higher than in its surroundings because of feces accumulation and therefore increased $\delta^{15} \mathrm{~N}$ in the soil organic matter. It would seem that the enclosure was actually used as a yard. Surprisingly, the lowest $\delta^{15} \mathrm{~N}$ values were recorded in close vicinity to the building ruins in comparison with the enclosure and the relict of the field. It would seem that the vicinities of the buildings where the soil samples were collected were actually free of livestock, although this requires further detail research.

The highest values of $\delta^{15} \mathrm{~N}$ close to buildings indicate that livestock was in all probability kept close to buildings or directly in barns in the investigated settlements in the village of Spindelbach. The steep decrease in $\delta^{15} \mathrm{~N}$ values at a distance above $100 \mathrm{~m}$ from the farm buildings indicates that the majority of the organic fertilizers were applied up to this distance. Furthermore, there was a decrease in $\delta^{15} \mathrm{~N}$ values at a distance between $100 \mathrm{~m}$ and $250 \mathrm{~m}$ indicating that this area was also affected by organic fertilizer application, although substantially less than the area up to $100 \mathrm{~m}$ from the building ruins. Values of $\delta^{15} \mathrm{~N}$ at a $250 \mathrm{~m}$ distance were the same as the values recorded at the end of the field at a $750 \mathrm{~m}$ distance from the building ruins. This indicates that the majority of the organic fertilizers were in all probability applied up to distance of $250 \mathrm{~m}$ from the buildings. Higher $\delta^{15} \mathrm{~N}$ values at a distance $500 \mathrm{~m}$ than in $250 \mathrm{~m}$ and $750 \mathrm{~m}$ indicates that certain organic fertilizers were in all probability also applied at a greater distance from the village or that there was a different use of agricultural land than at other distances, at least in certain transects. In order to answer questions connected with medieval farming practices in more detail, fine scale soil sampling must be performed. This was impossible in Spindelbach, however, where relicts of medieval fields at certain distances from the village were heavily damaged by recent forest management activities.

Similarly to other regions (Dupouey et al. 2002; Bogaard et al. 2007; Aquilera et al. 2008), ancient farming practices connected with livestock breeding and organic fertilizer application can be studied using $\delta^{15} \mathrm{~N}$ signature in contemporary forest soils in Central Europe. Although mineral $\mathrm{N}$, nitrates particularly, are highly mobile in the soil profile under a high precipitation regime (Svoboda, Haberle 2006), there is a low mobility of $\mathrm{N}$ fixed in organic matter. Nitrogen incorporated into soil organic matter can thus retain $\delta^{15} \mathrm{~N}$ signature generated by farming activities for centuries. This is given by the high stability of the soil organic matter fixing $\mathrm{N}$ for centuries particularly in forest soils (Chen et al. 2011).

\section{Acknowledgements}

Kateřina Součková and Michal Hejcman were supported by the project CIGA 20114208 and Tomáš Klír by the project GAČR P405/10/0556. We would like to thank Pavla Staňková for her assistance with field work and laboratory analyses. Lenka Lisá and Hana Šantrůčková are gratefully acknowledged for their useful comments.

\section{References}

AQUILERA, M., ARAUS, J. L., VOLTAS, J., RODRÍGUEZ-ARIZA, M. O., MOLINA, F., ROVIRA, N., BUXÓ, R., FERRIO, J. P. 2008: Stable carbon and nitrogen isotopes and quality traits of fossil cereal grains provide clues on sustainability at the beginnings of Mediterranean agriculture. Rapid Communications in Mass Spectrometry 22, 16531663.

BAKELS, C. C. 1997: The beginnings of manuring in Western Europe. Antiquity 71, 442-445.

BOGAARD, A., HEATON, T. H. E., POULTON, P., MERBACH, I. 2007: The impact of manuring on nitrogen isotope ratios in cereals: archaeological implications for reconstruction of diet and crop management practices. Journal of Archaeological Science 34, 335-343.

BOL, R., ERIKSEN, J., SMITH, P., GARNETT, M. H., COLEMAN, K., CHRISTENSEN, B. T. 2005: The natural abundances of ${ }^{13} \mathrm{C},{ }^{15} \mathrm{~N},{ }^{34} \mathrm{~S}$ and ${ }^{14} \mathrm{C}$ in archived (1923-2000) plant and soil samples from the Askov long-term experiments on animal and manure mineral fertilizer. Rapid Communications in Mass Spectrophotometry 19, 3216-3226.

CHEN, Y. T., BOGNER, C., BORKEN, W., STANGE, C. F., MATZNER, E. 2011: Minor response of gross $N$ turnover and $N$ leaching to drying, rewetting and irrigation in the topsoil of a Norway spruce forest. European Journal of Soil Science 62, 709-717.

COMMISSO, R. G., NELSON, D. E. 2007: Patterns of plant $\delta^{15} \mathrm{~N}$ values on a Greenland Norse farm. Journal of Archaeological Science 34, 440-450.

ČERNÝ, E. 1994: Die historich- geographische Erforschung der wüsten mittelalterlichen Dörfen und Fluren im Drahaner Hochland. Siedlungsforschung. Archäologie - Geschichte - Geographie 12, 125141.

CRKAL, J., ČERNÁ, E. 2009: Neue Entdeckungen im Erzgebirge wüstgelassene mittelalterliche Glashütten im Katastergebiet Výsluní (Sonnenberg), Bezirk Chomutov. Archaeologia Historica 34, 503-521.

DENIRO, M. 1987: Stable isotope and archaeology. American Scientist 75, $182-191$.

DUPOUEY, J. L., DAMBRINE, E., LAFFITE, J. D., MOARES, C. 2002: Irreversible impact of past land use on forest soils and biodiversity. Ecology 83, 2978-2984.

ELLERT, B. H., JANZEN, H. H. 2006: Long-term biogeochemical cycling in agroecosystems inferred from ${ }^{13} \mathrm{C},{ }^{14} \mathrm{C}$ and ${ }^{15} \mathrm{~N}$. Journal of Geochemical Exploration 88, 198-201.

FRASER, R. A., BOGAARD, A., HEATON, T., CHARLES, M., JONES, G., CHRISTENSEN, B. T., HALSTEAD, P., MERBACH, I., POULTON, P. R., SPARKES, D., STYRING, A. K. 2011: Manuring and stable nitrogen isotope ratios in cereals and pulses: towards a new archaeobotanical 
approach to the inference of land use and dietary practices. Journal of Archaeological Science 38, 2790-2804.

GEORGI, M., VOERKELIUS, S., ROSSMANN, A., GRASSMANN, J., SCHNITZLER, W. H. 2005: Multielement isotope ratios of vegetables from integrated and organic production. Plant and Soil 275, 93-100.

HEJCMAN, M., KARLÍK, P., ONDRÁČEK, J., KLÍR, T. 2013: Short-term Medieval Settlement Activities Irreversibly Changed Forest Soils and Vegetation in Central Europe. Ecosystems 16, 652-663.

HEJCMAN, M., ONDRÁČEK, J., SMRŽ, Z. 2011: Ancient waste pits with wood ash irreversibly increase crop production in Central Europe. Plant and Soil 339, 341-350.

HEJCMAN, M., SMRŽ, Z. 2010: Cropmarks in stands of cereals, legumes and winter rape indicate sub-soil archaeological features in the agricultural landscape of Central Europe. Agriculture, Ecosystems and Environment 138, 348-354.

JUNK, G., SVEC, H. J. 1958: The absolute abundance of the nitrogen isotopes in the atmosphere and compressed gas from various sources. Geochimica et Cosmochimica Acta 14, 234-243.

KLÁPŠTĚ, J. 2012: The Czech Lands in Medieval Transformation. Brill, Leiden.

KLÍR, T. 2009: Die ländliche Besiedlung Böhmens in Spätmittelalter und in der Frühneuzeit. Konzepte der Forschung. Beiträge zur Mittelalterarchäologie in Österreich 25, 147-160.

KLÍR, T. 2010: Rural settlements in Bohemia in the "age of transition" $\left(14^{\text {th }}-16^{\text {th }}\right.$ century): research concept and preliminary report. Medieval Settlement Research 25, 52-61.

KOERNER, W., DAMBRINE, E., DUPOUEY, J. L., BENOIT, M. 1999: $\delta^{15} \mathrm{~N}$ of forest soil and understorey vegetation reflect the former agricultural land use. Oecologia 121, 421-425.

KORBOVÁ PROCHÁZKOVÁ, L. 2011: The deserted medieval village in the "Mořina" locality near Běštín. Studia Mediaevalia Pragensia 10, $25-90$.

KRISZAN, M., AMELUNG, W., SCHELlBERG, J., GEBBING, T., KÜHBAUCH, W. 2009: Long-term changes of the $\delta^{15} \mathrm{~N}$ natural abundance of plants and soil in a temperate grassland. Plant and Soil 325, 157-169.
NEKUDA, R. 2007: The Agricultural Homestead in Moravian Mediaeval Villages. BAR International Series, 1582, Oxford.

NEKUDA, V. 2005: Das hoch- und spätmittelalterliche Dorf im Ostmitteleuropa im Licht der archäologischen Forschung. Archaeologia Historica 30, 263-328.

ROBINSON, D. 2001: $\delta^{15} \mathrm{~N}$ as an integrator of the nitrogen cycle. Trends in Ecology and Evolution 16, 153-162.

SAH, S. P., ILVESNIEMI, H. 2007: Interspecific variation and impact of clear-cutting on natural ${ }^{15} \mathrm{~N}$ abundance and $\mathrm{N}$ concentration in the needle-to-soil continuum of a boreal conifer forest. Plant, Soil and Environment 53, 329-339.

SENBAYRAM, M., DIXON, L., GOULDING, K. W. T., BOL, R. 2008: Long-term influence of manure and mineral nitrogen applications on plant and soil ${ }^{15} \mathrm{~N}$ and ${ }^{13} \mathrm{C}$ values from the Broadbalk Wheat Experiment. Rapid Communications in Mass Spectrometry 22, 1735-1740.

SIMPSON, I. A., BOL, R., DOCKRILL, S. J., PETZKE, K. J., EVERSHED, R. P. 1999a: Compound-specific $\delta^{15} \mathrm{~N}$ amino acid signals in palaeosols as indicators of early land use: a preliminary study. Archaeological Prospection 4, 147-152.

SIMPSON, I. A., BOL, R., BULL, I. D., EVERSHED, R. P., PETZKE, K. J., DOCKRILL, S. J. 1999b: Interpreting early land management through compound specific stable isotope analyses of archaeologicla soils. Rapid Communications in Mass Spectrometry 13, 1315-1 319.

SVOBODA, P., HABERLE, J. 2006: The effect of nitrogen fertilization on root distribution of winter wheat. Plant, Soil and Environment 52, 308-313.

VAŘEKA, P., HOLATA, L., ROŽMBERSKÝ, P., SCHEJBALOVÁ, Z. 2011: Die Besiedlung der Region Rokycany im Mittelalter und die Problematik von Dorfwüstungen. Archaeologia Historica 35, 319-342.

VOGEL, J. C., VAN DER MERWE N. J. 1977: Isotopic evidence for early maize cultivation in New York State. American Antiquity 42, 238-242. 
